\title{
REASONS FOR A SEMIOTIC APPROACH TO MATHEMATICS EDUCATION
}

\author{
RAZÕES PARA UMA ABORDAGEM SEMIÓTICA NA EDUCAÇ̃̃O MATEMÁTICA
}

DOI: http://dx.doi.org/10.23926/RPD.2526-2149.2019.v4.n1.p24-41.id350

\section{Michael Friedrich \\ Otte}

$\mathrm{PhD}$ in Mathematics from the University of Goettingen and Munster University

(Alemanha)

Visiting foreign Teacher at

the Federal University of

Mato Grosso (UFMT)

michaelontra@aol.com

\section{Geslane Figueiredo da Silva Santana}

Doctorating in Science and Mathematics Education (REAMEC)

Teacher at the Federal University of Mato Grosso (UFMT)

geslanef@hotmail.com

\section{Luciene de Paula}

Doctorating in Education at the Federal University of Mato Grosso (UFMT). Technician in Educational Affairs at the Federal

University of Mato Grosso (UFMT)

luciene.ufmt@gmail.com

\section{Luiz Gonzaga Xavier de Barros}

$\mathrm{PhD}$ in Mathematics from the University of São Paulo (USP)

Teacher at University Anhanguera of São Paulo (UNIAN) lgxbarros@hotmail.com

\begin{abstract}
Only recently has the semiotic approach become more acceptable or common in mathematics education research and analysis and has gradually disconcerted the Platonic foundation of mathematical objects. In fact it has become increasingly evident that the meanings of concepts develop in the social relationships. The objective is to present the reasons for the use of the semiotic approach in mathematical education. We are arguing, in fact, that the crystallization of mathematical concepts limits creativity and distances school learning from the day to day practices. In theoretical research, questions are addressed such as What is the $x$ in this equation?, evidencing a part of the work of Frege and Benacerraf, with more appreciation to the Peirce's Semiotic. Illustrative and important examples of such a perspective are presented. For example, the complementarity between text and diagram offers opportunities of critical reflections about the expected results of education in mathematics. Therefore, to think semiotically is to recognize that all knowledge is dynamic, despite being constructed through signs, implying responsibilities, either in choosing the strategy defined for each problem situation, or in identifying the meanings according to the given references and the interactions with the world.
\end{abstract}

Keywords: Mathematical Education; Philosophy of Mathematics; Semiotics; Mathematics.

Resumo: A abordagem semiótica no processo ensino-aprendizagem é assunto recente e, especialmente na matemática, vem, gradativamente, descontruindo a ideia platônica de que ela seja uma ciência infalível e inquestionável, isso porque cada vez mais é evidenciado que os sentidos das coisas se desenvolvem nas relações sociais. Objetiva-se apresentar razões para o uso da abordagem semiótica na educação matemática, defendendo que a cristalização dos conceitos matemáticos limita a criatividade e distancia a escola do mundo real, a qual deve estar aberta a possibilidades interpretativas. Nessa pesquisa teórica, são abordadas questões como $O$ que é $o x$ em uma equação?, evidenciando-se as pesquisas dos teóricos Frege e Benacerraf, assim como a semiótica peirceana; são apresentados exemplos importantes dessa perspectiva, como a complementaridade entre texto e diagrama, propondo reflexões críticas acerca dos resultados esperados da educação na disciplina matemática, uma vez que os objetos matemáticos são abstratos. Portanto, pensar semioticamente é reconhecer que todo conhecimento é dinâmico, apesar de ser construído por meio de signos, implicando em responsabilidades, seja na escolha da estratégia definida para cada situação problema, seja na identificação dos significados de acordo com as referências dadas, ou ainda na interação com o mundo.

Palavras-chave: Educação Matemática; Filosofia da Matemática; Semiótica; Matemática. 


\section{INTRODUÇÃO}

It is assumed that the reasons for the objections to semiotics in didactics and in the historiography of mathematics are similar and reside in the belief that mathematical knowledge is somewhat absolute knowledge. Teachers of mathematics as well as mathematicians themselves, think they know what mathematics really is, definitely and once for all.

In taking a semiotic approach, we recognize that things develop in social relations and cannot be reduced simply to the face value of language and symbols, although they are not separable from them. The semiotic approach assumes, in contrast, that human knowledge is always incomplete and that the form and content of mathematical theories cannot be definitive. It is therefore difficult sometimes to answer quite obvious questions, like for example: What is $\mathrm{x}$ ? You can't ask, real and definitely, what is $x$, even though you use such symbols in every thought and in every communication, because neither the sense nor the reference of a sign or word or a proposition can be determined definitely.

Even if it were possible to intuitively know what is $B$ or $X$, such information could not be added to our attention, since, as Kant says: "Thoughts without content are empty; intuitions without concepts, blind" (1998, A 51/ B 75).

Any geometric or algebraic proof is based on some mutual interdependence of text and diagram. The diagram provides a context that helps establish references and indicate the meanings of certain terms. The text, operating on the basis of conceptions, i.e. in universal terms, points out the possibilities for generalization of a given argument. The diagram is often perceived by means of its particular characteristics, that is, the diagram is commonly identified as a specific object.

For example, in the short proof of theorem 35 of book I of Euclid's Elements, the same word equal occurs more than 10 times with three different meanings: congruence, equal area and numeric identity.

\footnotetext{
The parallelograms which are on the same base and between the same parallels equal one another. Let $\mathrm{ABCD}$ and $\mathrm{EBCF}$ be parallelograms on the same base $\mathrm{BC}$ and in the same parallels $\mathrm{AF}$ and $\mathrm{BC}$. I say that $\mathrm{ABCD}$ equals the parallelogram EBCF. Since ABCD is a parallelogram,

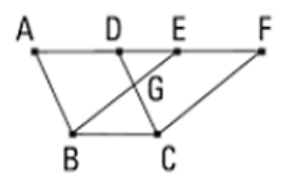
therefore $\mathrm{AD}$ equals $\mathrm{BC}$. For the same reason $\mathrm{EF}$ equals $\mathrm{BC}$, so that $\mathrm{AD}$ also equals $\mathrm{EF}$. And $\mathrm{DE}$ is common, therefore the whole $\mathrm{AE}$ equals the whole $\mathrm{DF}$. But $\mathrm{AB}$ also equals $\mathrm{DC}$. Therefore the two sides $\mathrm{EA}$ and $\mathrm{AB}$ equal the two sides FD and DC respectively, and the angle FDC equals the angle EAB, the exterior equals the interior. Therefore the base $\mathrm{EB}$ equals the base $\mathrm{FC}$, and the triangle $\mathrm{EAB}$ equals the triangle FDC. Subtract DGE from each. Then the trapezium ABGD which remains equals the trapezium EGCF which remains. Add the triangle GBC to each. Then the whole parallelogram $\mathrm{ABCD}$ equals the whole parallelogram $\mathrm{EBCF}$.
} 
Therefore parallelograms which are on the same base and in the same parallels equal one another. (EUCLIDES, 2009, p.124, our translation).

The figure represents a diagram provides the particular characteristics by means of intuition and of the representation of this diagram, and you can intuitively, speculating that these parallelograms are equal to each other. However, the text offers possibilities for generalization. However, even in this proof on is faced with the difficulty of interpreting the word equal and with the problem of the meaning of the concept equal. A mathematician can prove this theorem, using the tools of Euclid, but a teacher of mathematics, need to go beyond that and explain the differences in meaning.

In this sense, the objective is to point out reasons for the use of the semiotic approach in mathematical education, evidencing the researches of the theorists Frege and Benacerraf, as well as the Peirce's Semiotic. Defending that the crystallization of mathematical concepts limits creativity and leaves teaching away from the real world, which must be open to interpretive possibilities. Encouraging critical reflections on issues such as What is $x$ in equation?, Reflecting that mathematical objects are abstract. All knowledge is dynamic, although it is constructed through signs, implying that it will never be final, complete and definite.

\section{CRYSTALliZATION OF MATHEMATICS VS. MATH EDUCATION}

The apparently static and infallible character of mathematical knowledge is one of the major problems for developing mathematics education. Everything appears to be equal to itself, i.e., $A=A$. This principle is at the core of the exact sciences and, obviously, is guided by the following line against any historical or evolutionary concern. $A$ means just $A$. No comment, no historical research, or psychological or philosophical consideration can add anything to it. Mathematics seems so unchanging and absolute, that the sociology and sociocultural history of knowledge did exclude mathematics from its considerations. It is thus an interesting fact to suppose that the sociology of knowledge, is really a sociology of error and deviation. (MANNHEIM, 1929, cited OTTE, 2012, p. 123).

In this context, it is often considered, in particular by mathematicians, that mathematics does not have a history worth knowing. The recent state of the art of mathematics has taken up and reformulated, in definite terms, which topics should be studied in the history of mathematics. Some mathematicians claim that any additional considerations to comings and goings in the history of mathematics are not relevant to mathematics education. If there is a story about some mathematical fact, it will be another hobby, for the common opinion of what constitutes the major trends of mathematics over the centuries is the accepted standard of all, 
that is, the history of mathematics is partly a dogma constituted by anecdotes or biographical stories. This dogmatic attitude, based on a casual and individualistic discussion, excludes all intrinsic views of mathematics, such as the reality of abstract and universal things inhibiting the records for scientific reflections, such views are the result of philosophical nominalism and an overestimation of individual creativity.

Looking at mathematics in this way, however, leaves it as set of completed works and finished theories that might reveal their secret beauty to the talented discoverer sometimes, but which could not be taught nor learned nor further developed. Being a mere form of reality, or a reality sui generis, mathematics has nothing to do with human activities or emotions. Such a view does not allow, for example, considering unresolved problems. This is not good, because great problems and programs of their investigation amount to the greater part the real history of mathematics (OTTE, 2012, p. 123-124). Therefore:

\section{Man creates his representations mechanically: what man does, believes, knows and thinks is also interfered with ideas (representations) previously elaborated; at the same time, the new representations generate transformations in the production of its existence (ANDERY et al, 2014, p.12, our translation).}

The human being is a historical being. That is fact! However, history can be read in many ways and it is exactly in the differences, in the comings and goings, in the peculiarities, in the advances and setbacks that the uncertainty is characterized and the mathematical activity is discovered. The importance attributed to historical events and the reflection that deals with them, is what enables man to be a social and historical subject. And it is precisely in this new context that mathematical education has gained its space.

The success of mathematics education does not depend on revisions of content and overly elaborate methodologies, but on the dynamization of mathematics itself when interacting between practice and knowledge, that is, it fundamentally depends on the teacher to recognize that mathematics is an integral part of the knowledge that is renews and strengthens itself through the experiences lived by all.

\section{Frege's INTERPRETATION FOR A = B}

All scientific and activity, in particular mathematical activity, begins by asking certain questions and considering certain problems. As Hilbert emphasized this in his address tospeech at the International Congress in Paris in 1900:

The deep significance of certain problems for the advance of mathematical science in general and the important role which they play in the work of the individual investigator are not to be denied. As long as a branch of science offers an abundance of problems, so long is it alive; a lack of problems foreshadows extinction or the 
cessation of independent development. Just as every human undertaking pursues certain objects, so also mathematical research requires its problems. It is by the solution of problems that the investigator steels himself; he finds new methods and new outlooks, gaining a wider and freer horizon. (1990, p. 1).

Therefore, it makes sense to look at mathematics from an evolutionary or historical perspective, just as it is accepted that scientific knowledge is incomplete and develops with humanity. The semiotic approach becomes really important when it is admitted that our knowledge will never be final, complete and definitive.

Mathematics deals with the relations of the equal and the different. Thus, $A=B$ is the most important diagram for mathematics, but it can be interpreted in two essentially different ways: as a relation between two signs representing the same object or as a relation between two objects possessing a common property.

German mathematician, logician and philosopher Friedrich Ludwig Gottlob Frege (1848 - 1925) opted for the first interpretation to deal with the problem of intentional contexts. His classic example was that Hesperus, the name of the Evening Star, and Phosphorus or Lucifer, the name of the Morning Star, represent the same object, that is, the planet Venus.

The identity of the object, however, does not make it correct to call Venus on the afternoon of Phosphorus, because one could argue that there are no linguistic relations at play. What is said, in fact, is that the brightest celestial body other than the moon which is sometimes seen to precede the rising sun in the East is the same as that star which at other times shines in the West after sunset of the sun. This is an empirical fact. The claim that Hesperus is Phosphorus has nothing linguistic about itself.

But, things become quite different when dealing with intensional contexts. In the sentence: Mister M. wants to know whether Hesperus is Phosphorus, one may not replace Hesperus by Phosphorus, because Mister M. does not want to know whether Phosphorus is Phosphorus.

Frege had identified sense or meaning with the way the references are given, such that concepts or functions must necessarily refer to an extension. Frege argued in favor of the extensionality of mathematics:

For the mathematician, it is no more correct and no more incorrect to define a conic section as the circumference of the intersection of a plane and the surface of a right circular cone than as a plane curve whose equation with respect to rectangular coordinates is of degree 2. Which of these two definitions he chooses, or whether he chooses another again, is guided solely by grounds of convenience, although these expressions neither have the same sense nor evoke the same ideas. (1952, p. 80). 
In the dynamics of the acquisition of knowledge the intensions and extensions take on a greater independence from one another. We constantly change from an intensional viewpoint, which substitutes the objects by their concepts and back to an extensional perspective, which conceives the objects as mere elements of a set, and distinguishes them.

Two concepts $A$ and $B$ are not the same, even if contingently or necessarily all $A$ are $B$ and vice versa, because different concepts help to establish different types of relationships and thus influence the development of Knowledge different ways.

In fact, with respect to cognitive growth, as well as to the foundations of knowledge, it seems relevant, or even essential, to know which definition is chosen, what perspective is taken or how a problem is represented.

\section{THE PROBLEM OF IDENTIFICATION}

Paul Benacerraf, in What Numbers Could not Be (1985), developed a philosophical argument against Platonism, which is called Identification Problem. He argues that it is not possible to unambiguously identify the natural numbers in a set-theoretic framework. This means that one cannot answer the question: What are numbers really?

For this question, it can be said that numbers are concepts given in terms of axiomatic structures like other mathematical concepts. The justifications of these theoretical structures are provided by their applications.

To insist on the absolute questions of the type What is this or that? would mean accepting that if $A$ is a number, the equation $A=B$ would make sense for whatever $B$ is. But, can $B$ be a number? Is $B$ a number, whatever $B$ might designate? And it made in fact sense for Frege to ask of any two names or descriptions whether they named the same object or different ones. Hence Frege complained that with this definition it could not be decided whether " [...] Julius Caesar was a number" (BENACERRAF, 1985, p. 286).

The work of Benacerraf has indeed become a significant catalyst in the motivation of the development of structuralism in the philosophy of mathematics.

The problem with Frege is his conception of logic as a universal language (HEIJENOORT, 1967). Seeing the nature of equality in substitutability, and Frege does so, one has to accept that substitutability is usually limited to a given context (FREGE, 1884, paragraph 65). For example, I cannot ask "[...] whether England is the same as the direction of the axis of the earth" ${ }^{1}$ (Ibid. paragraph 66, our translation). Benacerraf comments that:

${ }^{1}[\ldots]$ ob England desselb sei wie die Richtung der Erdaxe. 
[...] Identity statements make sense only in contexts where there exist possible individuating conditions. If an expression of the form ' $\mathrm{x}=\mathrm{y}$ ' is to have sense it can only be in contexts where it is clear that both $\mathrm{x}$ and $\mathrm{y}$ are of some kind or category $\mathrm{C}$ (1985, p. 286).

However, such categorizations are not absolute and static, they depend on the activity and its goals and means. Take as an example the theory of economic value. The economic equation of two commodities, such as 1 suit $=2$ pairs of shoes, depends on the context, it holds on the market place only, because the suit and the two pairs of shoes have only their exchange value in common, and nothing else and therefore cannot be equated in other contexts. A person may need a suit, but may not want new shoes. And the situation where someone is willing to change a suit for a pair of shoes obviously depends on how urgently she needs these shoes and how much she values them.

In the opening chapter of Capital, Karl Marx (1818 - 1883) reflects on such questions:

Every useful thing, as iron, paper, \&c., may be looked at from the two points of view of quality and quantity. It is an assemblage of many properties, and may therefore be of use in various ways. To discover the various uses of things is the work of history. So also is the establishment of socially-recognized standards of measure for the quantities of these useful objects. The diversity of these measures has its origin partly in the diverse nature of the objects to be measured, partly in convention. [...] Exchange value, at first sight, presents itself as a quantitative relation, as the proportion in which values in use of one sort are exchanged for those of another sort, a relation constantly changing with time and place. [...] A given commodity, e.g., a quarter of wheat is exchanged for x blacking, y silk, or z gold, \&c. - in short, for other commodities in the most different proportions. Instead of one exchange value, the wheat has, therefore, a great many. But since $\mathrm{x}$ blacking, y silk, or $\mathrm{z}$ gold \&c., each represents the exchange value of one quarter of wheat, $x$ blacking, y silk, $z$ gold, \&c., must, as exchange values, be replaceable by each other, or equal to each other. (MARX, 1967, p. 35-36).

It is in the same way that the number arises in all contexts of comparison, measurement or counting, representing the essence of these types of relationships. Similarly the eminent physicist Richard Philips Feynman (1918 - 1988) compares the different formulations of classical mechanics given by Newton, Lagrange and Hamilton and illustrates this point of view well by stating:

[...] Mathematically each of the three different formulations, Newton's law, the local field method and the minimum principle, gives exactly the same consequences. What do we do then? You will read in all the books that we cannot decide scientifically on one or the other. That is true. [...] But psychologically they are very different in two ways. First, philosophically you like them or do not like them;[...]. Second, psychologically they are different because they are completely unequivalent when you are trying to guess new laws. As long as physics is incomplete, and we are trying to understand the other laws, then the different possible formulations may give clues about what might happen in other circumstances. (1967, p. 53).

David Joseph Bohm (1917 - 1992) who acted in the field of quantum physics presents an additional argument in this direction: 
It was widely believed in the nineteenth century that Newtonian dynamics and Hamilton-Jacobi wave theory of dynamics were essentially the same. Nevertheless we can now see that the difference between wave dynamics and particle dynamics was potentially of very great relevance in the sense that the form can lead in a natural way to quantum theory, while the latter cannot. (1977, p. 383).

In these perspectives presented, one can also conceive $A$ and $B$ as distinct aspects, that is, as different objects and then finally conclude that the equation $A=B$ designates an equal aspect or a relation between these apparently things many different.

\section{SEMIOTIC APPROACH}

It may be strange for an impartial observer to note the obstinacy with which philosophers discuss the question about the nature of mathematical objects, while mathematics teachers and pedagogues seek to avoid absolute questions such as, What is it? Peano's axioms do not answer such questions. "What is the number 1 , or 2" in an absolute and definite manner. Numbers could be anything, even games - like Hackenbusch-Games or Conway-Numbers (FONSECA, 2010), Vectors (NASCIMENTO, 2013), Chessboard (WIELEWSKI, 1998); Computer Program (SILVA, 2009), etc. Even in the context of set-theory very different representations of the number system could be given as Paul Benacerraf has shown (Benacerraf, 1985).

Some authors conclude that "[...] detecting or interacting with mathematical object does not seem to constitute any part of mathematical practice." (CHIHARA, 2004, p.13). On the other hand, it is known that there is a wide variety of interpretations in relation to the models of arithmetic that contribute to the understanding of the concept of number and also help to avoid both static essentialism ${ }^{2}$ and simple nominalism ${ }^{3}$. Even arithmetic does not describe specific mathematical objects, instead it merely describes structural relationships.

The perspective that all thought occurs in terms of signs, it follows that to interpret something means to represent it. According to the scientist, logic and philosopher Charles Sanders Peirce (1839-1914):

Man makes the word, and the word means nothing which the man has not made it
mean, and that only to some man. But since man can think only by means of words or
other external symbols, these might turn round and say: "You mean nothing which we
have not taught you, and then only so far as you address some word as the interpretant
of your thought". [...] the word or sign which man uses is the man himself. For, as the
fact that every thought is a sign, taken in conjunction with the fact that life is a train

\footnotetext{
2"The current of thought introduced and defended by Aristotle, according to which scientific research must penetrate even the essence of things in order to explain them." (POPPER apud ABBAGNANO, 2007, p.363, our translation).

3 "[...] doctrine according to which the language of the sciences contains only individual variables, whose values are concrete objects, not classes, properties, and the like".(ABBAGNANO, 2007, p.715, our translation).
} 
of thought, proves that man is a sign; so, that every thought is an external sign, proves that man is an external sign. (PEIRCE, CP 5.314).

The essence of something is no more than the essence of a representation of that thing, and the essence of a representation of a thing is only the essence of a second representation of the representation of that thing, and so on.

In this way, neither the final object, let alone the definitive meaning of a sign, can be given. Therefore, semiosis extends in both directions, in relation to the object, where there is no definitive reference, as well as to the interpretant, in which there is no definitive interpretation, and the interpretant itself becomes only a translation or development of the original sign. Therefore, Peirce distinguishes the two objects of the sign, that is, "[...] the immediate object, or the object as the sign represents it, from the dynamical object or really efficient but not immediately present object." (CP 8. 343). This distinction must also be observed in the relation between immediate interpretant ${ }^{4}$ and dynamic interpretant ${ }^{5}$.

The fundamental triad in Peirce's semiotics is Triadic relation of Sign-ObjectInterpretant. (CP 8.361). The relation of a sign to its object decomposes the sign into three main categories:

There are three kinds of signs which are indispensable in all reasoning; the first is the diagrammatic sign, or icon, which exhibits a similarity or analogy to the subject of discourse; the second is the index, which like a pronoun demonstrative or relative, forces the attention to the particular object intended without describing it; the third [or symbol] is the general name or description which signifies its object by means of an association of ideas or habitual connection between the name and the character signified. (PEIRCE, CP 1.369).

To illustrate Corrêa (2008, p.98), a statue can be seen as an Icon, when one observes the similarity with the represented individual, whereas fever is an Index, when it indicates the existence of a infection and finally the word $\operatorname{dog}$ is a symbol, which will be interpreted as a result of a cultural practice, meaningful only for people who have the habit of speaking English.

This triad indicates an inherently dynamic process of the sign, which is not controlled by an independent human agent and according to his desires. For example, the process of communication is not the meeting of independent actors, who decide to say what comes to their mind. Instead, communication is a social system, a system that does not interact directly with people's minds or consciences and is not arbitrarily constructed by participants. Human agents

\footnotetext{
4"The immediate interpretant consists in what the sign is capable of producing in any interpreting mind. It is not a question of what the sign actually produces in my mind or in my mind, but of what, depending on its nature, it can produce"(SANTAELLA, 2007, p.13, our translation).

5 5“...] the dynamic interpretant, that is, what the sign actually produces in its own, in my mind, in each singular mind. And this it will produce depending on its nature of sign and its potential as a sign" (SANTAELLA, 2007, p.13, our translation).
} 
are subsystems, or rather, they must constitute themselves as these subsystems of the social system of communication. To describe this situation Peirce uses the phrase: "[...] man is an external sign" CP 5.314).

The most important prerequisite for learning and knowledge is the possibility of simultaneously facing a set of knowledge, as well as its development or application. This possibility is provided only by social cooperation. Concepts and tools of human activity serve as substitutes for direct cooperation. With them, people are creative, sensing new meanings within the established system of concepts and tools and acting on these new meanings.

In New Essays on Human Understanding, Leibniz, arguing with Locke, exemplified:

Someone in distress needs an ammunition for a pistol, but has no lead to melt and build; and a friend tells him, 'Remember that the money you have in your purse is fuse.' This friend will not teach you a good quality of money, but will make him think about the use he can make, to have the ammunition in that urgent need. ${ }^{6}$ (LEIBNIZ, 1993, our translation).

One can interpret a hammer as a tablecloth, but what will be the result? On the other hand, a hammer can be used as a pendulum or as a weight on a scale, depending on the problem in question.

A truly fertile semiotic approach does not refer to a merely conventional approach, but to detailed and careful analysis. Even if one admits that, in a way, everything can be similar to almost everything, this will depend on the context. The objectivity of our knowledge is shown in its applications.

\section{THE DIAGRAMMATIC REASONING}

The philosopher and mathematician Immanuel Kant (1724-1804) emphasized that the principle of consistency only applies if there is a given object. The statement that " [...] a triangle has three angles $[. .$.$] does not say that three angles are absolutely necessary, but rather that under$ the condition that a triangle exists (is given), three angles also exist (in it) necessarily." (1998, A 593/ B 621 - A 594/ B 622).

Mathematical concepts are schemes of operation and have become functions of cognitive activity, rather than being the result of abstraction. A classic and much discussed example is George Berkeley's (1685-1753) criticism of ideas about the general triangle formulated by John Locke (1632-1704). Locke stated that:

\footnotetext{
${ }^{6}$ Quelqu'un a besoin dans le danger d'une balle de pistolet et manqué de plomb pour en fondre dans la forme qu'il a; un ami luy dit: souvenés vous que l'argent que vous avez dans votre bourse, est fusible; cet ami ne luy apprendra point une qualité de l'argent mais il fera penser à une usage qu'il en peut faire pour avoir des balles a pistolet dans ce pressant besoin.
} 
$[\ldots]$ are not so obvious $[\ldots]$ as particular ones $[\ldots]$ For example, does it not require some pains and skill to form the general idea of a triangle [...]for it must be neither oblique, nor rectangle, neither equilateral, equicrural, nor scalenon; but all and none of these at once. (1690, IV 9.7).

In contrast, Berkeley asked readers of Locke's Essay on Human Understanding to try to find out if they could have "[...] an idea that shall correspond with the description here given[...].” (BERKELEY, 1910, Int. 13). Berkeley proposed a representational solution to this logical dilemma by saying that:

[...] we shall acknowledge that an idea, which considered in itself is particular, becomes general, by being made to represent or stand for all other particular ideas of the same sort. [...] Universality, so far as I can comprehend, is not consisting in the absolute positive nature or conception of anything, but in the relation it bears to the particulars signified or represented by it $[. .$.$] how we can know any Proposition to be$ true of all particular Triangles, except we have first seen it demonstrated of the abstract Idea of a Triangle which equally agrees to all? [...]. (1910, Int. 12-16).

And Berkeley continues, this is where the new formalism enters:

To which I answer that though the idea I have in view whilst I make the demonstration, be for instance that of an isosceles rectangular triangle whose sides are of a determinate length, I may nevertheless be certain it extends to all other rectangular triangles of what sort or bigness so-ever. And that because neither the right angle, nor the equality nor determinate length of the sides are at all concerned in the demonstration. It is true, the diagram I have in view includes all these particulars, but then there is not the least mention made of them in the proof of the proposition. (1910, Int.16).

Any such proof is based on some mutual interdependence of text and diagram. As already stated at the beginning, the diagram provides a context that helps to set references and indicate the meanings of certain terms. The text reminds us to take certain quantities of the diagram as variables, just as Berkeley pointed out. Moreover, the text, operating in terms of general and concept-based words, indicates possibilities of generalizing certain proof, while the diagram is often perceived in its defined and largely accidental features, almost as a specific object.

For example, the theorem 35 in Book I of Euclid's Elements (2009), it seems that the parallelograms $A D B C$ and $E F B C$ are congruent, because it has the same area, but in fact it is: $A B C D$ is equal to the parallelogram $E B C F$.

In geometry there are two methods for introducing generality: by means of the continuity principle, synthetic point of view, or by algebraic coordinates, analytic point of view (OTTE, 1997). In the early nineteenth century, Jean Victor Poncelet (1788-1867), Joseph Diez Gergonne (1771-1859), among others, entered into a great dispute over the advantages of each of these perspectives. Over time, the analytic context has imposed itself on the synthetic, because mathematicians have begun to take an interest in spaces of more than three dimensions. 
A detailed analysis of the mutual interdependence of the text and the diagram is given, along a conventional proof of Euler's theorem, by stating that the competition points of the perpendicular bisectors, medians and altitudes of any triangle are collinear. The line determined by them is called the Euler line of a triangle (OTTE, 2006).

And we have shown how (Ibid.), by comparing what is said in the text and what can be seen from the diagram, this proof could be stepwise generalized such that one finally arrives at a Desarguen configuration. The existence of the Euler line is now guaranteed by the reciprocal of the Desargues theorem, which states that if the intersections of the corresponding sides of two different triangles $A B C$ and $A^{\prime} B^{\prime} C^{\prime}$ (or extensions) are on the same line, then the lines through the corresponding vertices pass through the same point. The Euler's theorem itself is seen to belong to the context of projective geometry, rather than Euclidean geometry.

A general triangle is general only in relation to a particular purpose or function and within a given theoretical context. If the task, for example, is to prove the theorem that the medians of a triangle intersect at a single point, the triangle on which the proof is to be based can be assumed to be an equilateral triangle, without loss of generality, because theorem in the case is a theorem of affine geometry and any triangle is equivalent to an equilateral triangle under like transformations, where equivalence or generality should be considered the light of a theory.

In axiomatic theory, two objects are considered equal if they are functionally equivalent in a certain way specified by the theory. In order to establish a relation of equality in this context, it is necessary to highlight the functions and predicates that make up the substitution axioms and that distinguish the equality from other equivalence relations, in which everything depends on the most appropriate theory to be applied in each type of problem.

Consider the following example: the catenary and the parable are almost indistinguishable, especially near the vertex, and Galileo Galilei (1564-1642) believed that they were in fact equal. Only about a hundred years later, the Dutch physicist Christiaan Huygens (1629-1695) and Gottfried Wilhelm Leibniz (1646-1716) discovered that the description of the catenary is given by a hyperbolic function, while the parabola by a second-degree function (OTTE, 2015).

One may think that it is very relative, the preferred choice, either the geometric or the algebraic, because on topology optics, both curves are the same, however, in a physical and practical interpretation, it may be reasonable to assume a dynamics. By analyzing a dangling current, that is, the catenary in a suspended bridge, and assuming that the suspension cables 
form a parabola, it is perceived that the distribution of forces in the two cases is very different. Then, from a dynamic point of view, the catenary and the parabola should be considered as different curves.

Frege's Platonism seems to take the inscrutability of ideal objects in the sense of the common set theoretical Platonism into account, because he connects the definition of numbers with their application. Frege claims:

[...] that the numerical indication contains a statement about a concept. This is perhaps most evident in the case of the number 0 . If I say "Venus has 0 moons," there is absolutely no moon or aggregate of moons that could be enunciated; but to the concept of the "moon of Venus" is thus given a quality, namely, that of assuming nothing. If I say "Emperor's chariot is pulled by four horses", I attribute number four to the concept "horse pulling emperor's chariot" 7 ". (1884, paragraph 46, our translation).

Frege avoids the essentialism of classical Platonism and seems to avoid its dilemma, namely, its incapability to answer the question, How can we humans have grasp of, or insight into, the realm of ideal or abstract objects? However, Frege does not offer a suitable account of mathematical epistemology. The problem results again from Frege's conception of logic as a universal language and the resulting view of application as conceptual description. Frege consequently considered existence to be a second-order predicate. McGinn illustrates this view of existence as follows:

[...] When you think that tigers exist you do not think of certain feline objects that each has the property of existence; rather, you think, of the property of tigerhood, that it has instances. [...] The concept of an object existing simply is the concept of a property having instances. (2000, p.18).

If existence pure and simple is ruled out and mathematization as an explorative activity that confronts the yet unknown and uncategorized becomes inconceivable. Frege's view of existence results from his universality of logic and from the resulting neglect of the role of indices, i.e. signs of contextual character.

Heijenoort was the first to very clearly point out the semantic peculiarities in connection of Frege's conception of logic as a universal language:

The universality of logic expresses itself in an important feature of Frege's system. In that system the quantifiers binding individual variables range over all objects. As is well known, according to Frege, the ontological furniture of the universe divides into objects and functions. Boole has his universal class, and De Morgan his universe of discourse denoted by ' 1 '. But these have hardly any ontological import. They can be changed at will. The universe of discourse comprehends only what we agree to

\footnotetext{
${ }^{7}[\ldots]$ dass die Zahlangabe eine Ausssag von einm Begriffe enthalte. Am deutlichsten ist dies vielleicht bei der Zahl 0. Wenn ich sage: "die Venus hat 0 Monde ", so ist gar kein Mond oder Aggregat von Monden da, von dem etwas ausgesagt werdwn Könnte; aber dem Begriffe "Venusmond" wird dadurch eine Eigenschaft beigelegt, nämlich die, nichts unter sich zu befassen. Wenn ich sage: "der Wagen des Kaisers wird von vier Pferden gezogen", so lege ich die Zahl vier dem Begriffe "Pferd, das den Wagen des Kaisers zieht" bei.
} 
consider at a certain time, in a certain context. For Frege it cannot be a question of changing universes. One could not even say that he restricts himself to one universe. His universe is the universe. Not necessarily the physical universe, of course, because for Frege some objects are not physical. Frege's universe consists of all that there is, and it is fixed (HEIJENOORT, 1967).

Logic or mathematical calculation is a kind of diagrammatic reasoning. In the development of pure mathematics, during the nineteenth and twentieth centuries, two very different movements prevailed. On the one hand, the rigorous movement of arithmetization, and, on the other hand, the axiomatic movement, which originated in the Poncelet or Peirce emphasis on the principle of continuity. Mathematics or axiomatic mathematics as a diagrammatic reasoning represents a genetic perspective aimed at generalization, while mathematics as arithmetic or set theory is concerned primarily with grounding and separation. All mathematical reasoning is diagrammatic and "[...] all necessary reasoning is mathematical reasoning, no matter how simple it may be (PEIRCE, CP. 5.148).

The diagrams are essentially icons, and the icons are particularly suited to make the possible and general understandable, rather than the actual and existing ones. Diagrams, however, can also include indexes, which are signs that indicate, denote or are actually linked to something particular. Diagrams, be they geometric or algebraic, serve to fix the references. In this way, they are established by the complementarity ${ }^{8}$ of icons and indexes. However, although iconicity represents the dominant character of mathematical diagrams, it is indexicality that makes the semiotic approach inevitable, because it shows that mathematical reasoning is contextual and that mathematics is not a formal and universal language. The relevant contexts are the semiotic contexts. Peirce writes:

One might think, that there would be no use for indices in pure mathematics, dealing, as it does, with ideal creations, without regard to whether they are anywhere realized or not. But the imaginary constructions of the mathematician, and even dreams, are so far approximate to reality as to have a certain degree of fixity, in consequence of which they can be recognized and identified as individuals. (CP, 2.305).

It seems ironic that Frege himself could not avoid indices in his explanation of the difference between meaning and reference in terms of geometric diagram. In the famous essay On Sense and Reference, he cites a few examples of elementary geometry. And writes:

[...]Let $\mathrm{a}, \mathrm{b}, \mathrm{c}$ be the lines connecting the vertices of a triangle with the medians on opposite sides. The point of intersection of $a$ and $b$ is the same as the point of intersection of $b$ and $c$. Therefore, we have different designations for the same point, and these names ('intersection point of $a$ and $b$ '; 'intersection point of $b$ and $c$ '),

\footnotetext{
${ }^{8}$ Complementarity, based on Pierce's semiotics, states that in order to characterize concepts or ideas connected with mathematical education, it is necessary to present them, not as a mere duality, but rather by performing an individual epistemological act and a complementary asymmetrical role. Although apparently contradictory, they complement each other.
} 
likewise indicate the mode of presentation, and consequently the sentence contains a real knowledge.9 (FREGE, 1892, parágrafo 26, our translation).

Assuming that, in the course of construction, these two points are marked, intersection point of $a$ and $b$ and intersection point of $b$ and $c$, and then it is surprisingly found that these two points coincide. The letters $a, b, c$ are mere indices, denomination of points, and their meaning is restricted to the context of a given geometric diagram and the same is true of the point of intersection of $a$ and $b$ and point of intersection of bec. In this view, this equation would be interpreted as a relation between two different objects, as Frege did, when considering the equation as a relation between two different designations of the center of gravity of the general triangle.

\section{CONSIDERATIONS}

The semiotic approach does not admit that the objects of the universe are fixed and are immutable, on the contrary, it recognizes that human activity can work with objects still unknown in their essence. And mathematics, as well as scientific practice, decides what types of objects must be assumed. Obviously, objective reference is important, but it does not need to be given and fully described in advance. In other words, the central fact for the applicability of mathematics is the partial independence of meaning and reference of symbolic representations.

In Frege's theory the sense of a term is a mode of presentation of an already definitely described object. Such conception of sense is completely inappropriate to the dynamics of knowledge mathematical, according to Benacerraf. The complementarity of meaning and reference, that is, the complementarity between a concept and the way in which it is presented, is essential as far as the evolution of all knowledge is concerned. The meaning of symbols is omnipresent, but semiotics is not reductionist, it flourishes over differences and these are the engine of discovery.

To this end, one must have the capacity to merge the two poles of the classical semiotic heritage, the epistemologically focused tradition, which emphasizes the importance of the indicative sign and the grounded linguistic tradition, which studies the conventional symbol.

\footnotetext{
${ }^{9}[\ldots]$ Es seien a, b, c die Geraden, welche die Ecken eines Dreiecks mit den Mitten der Gegenseiten verbinden. Der Schnittpunkt von a und b ist dann derselbe wie der Schnittpunkt von b und c. Wir haben also verschiedene Bezeichnungen für denselben Punkt, und diese Namen ("Schnittpunkt von a und b“; „Schnittpunkt von b und c“) deten zugleich auf Art des Gegenseiten, und und daher ist in dem Satze eine wirliche Ekenntnis enthalten”.
} 
In mathematics education, it is necessary to seek mechanisms that transpose the duality between the presented concepts so that teachers can perceive and understand what has been called by complementarity and, in fact, contribute to a participatory, critical and responsible school for their choices.

\section{REFERENCES}

ABBAGNANO, Nicola. Dicionário de Filosofia. 5ªed. São Paulo: Martins Fontes, 2007.

ANDERY, Maria Amália et al. Para compreender a Ciência: uma perspectiva histórica. Rio de Janeiro: Editora Garamond, 2014.

BENACERRAF, Paul. What Numbers could not be; reprinted 1985 in: Benacerraf/ Putnam (eds), Philosophy of Mathematics, Cambridge University Press, London, 1965.

BERKELEY, George. 1710/1957. A treatise concerning the principles of human knowledge. Indianapolis, IN: Bobbs-Merrill, 1710.

BOHM, David Joseph. Science as Perception Communication, in: F Suppe (Ed), The Structure of Scientific Theories, Urbana: University of Illinois Press, 374-423, p. 383f), 1977.

CHIHARA, Charles. A Structural Account of Mathematics. Oxford: Clarendon Press, 2004.

CORRÊA, Isabella Moreira de Paiva. Como se fala matemática? Um estudo sobre a complementaridade entre representação e comunicação na educação matemática. 2008. 154f. Dissertação (Mestrado em Educação) - Universidade Federal de Mato Grosso, Cuiabá, 2008.

CORRÊA, Isabella Moreira de Paiva. Como se fala matemática? Um estudo sobre a complementaridade entre representação e comunicação na educação matemática. 2008. 154f. Dissertação (Mestrado em Educação) - Universidade Federal de Mato Grosso, Cuiabá, 2008.

EUCLIDES. Os Elementos. Tradução de Irineu Bicudo. Rio Claro: Unesp, 2009.

FEYNMAN, Richard. The Character of Physical Law. Cambridge: MIT Press, 1967.

FONSECA, Rogério Ferreira da. A Complementaridade entre os Aspectos Intensional e Extensional na Conceituação de Número Real Proposta por John Horton Conway. 2010. 182 f. Tese (Doutorado em Educação Matemática) - Pontifícia Universidade Católica de São Paulo, São Paulo, 2010.

FREGE, Gottlob. Die Grundlagen der Arithmetik, Breslau, 1884.

FREGE, Gottlob. Ñber Sinn und Bedeutung, Zeitschrift für Philosophie und philosophische Kritik NF 100, 25-50, 1892. 
FREGE, Gottlob. Illustrative extracts from Frege's review of Husserl's Philosophie der Arithmetik I. In: Translations from the Philosophical Writings of Gottlob Frege. Ed. by Peter Geach and Max Black. Oxford: Blackwell, p. 79-85, 1952.

HEIJENOORT, Jean Van. Logic as Calculus and Logic as Language. Synthese. New York: Springer, v. 17, p. 324-330. 1967.

HILBERT, David. Mathematical Problems: Lecture delivered before the International Congress of Mathematicians at Paris in 1900. Disponível em:

<https://mathcs.clarku.edu/ djoyce/hilbert/problems.html > . Acessado em: 02 jul. 2018.

KANT, Immanuel. Critique of Pure Reason. Translated and edited by Paul Guyer and Allen W. Wood. Cambridge: Cambridge University Press, 1998.

LEIBNIZ, Gottfriend Wilhelm. Nouveaux Essais sur l'Entendement Humain. Paris: Editions Flamarion. 1993.

LOCKE, John. An Essay Concerning Human Understanding. New York: Oxford University Press, 1690 (1975).

MANNHEIM, Karl. Ideologie und Utopie. Frankfurt, 1929.

MARX, Karl. Capital: A Critique of Political Economy. Vl. 1. New York, NY: International Publishers, 1967.

MCGINN, Colin. Logical Properties. Oxford: Claredon Press, 2000.

NASCIMENTO, Demilson Benedito. Hermann Günter Grassmann (1809-1877) e o Desenvolvimento do Pensamento Geométrico: A Complementaridade Entre Alguns Aspectos da Die Lineale Audehnungslehre (1844). 2013. 189 f. Tese (Doutorado em Educação) - Universidade Federal de Mato Grosso, Cuiabá, 2013.

OTTE, Michael Friedrich. Analysis and Synthesis in Mathematics from the Perspective of Charles S. Peirce`s Philosophy. In: Otte, M./M. Panza (eds.), Analysis and Synthesis in Mathematics: History and Philosophy. Boston Studies in the Phil. Of Science, vol. 196, Kluwer, 327-364, 1997.

OTTE, Michael Friedrich. Proof analysis and Continuity, Foundations of Science, vol. 11, p. 121-155, 2006.

OTTE, Michael Friedrich. A Realidade das Ideias: uma perspectiva epistemológica para a Educação Matemática. Cuiabá, MT, Editora da UFMT, 2012.

OTTE, Michael Friedrich.; BARROS, Luiz Gonzaga Xavier de. Creativity, Tacit Knowledge and Mathematics Education. Caminhos da Educação Matemática em Revista, On line - v. 3, n. 1, p. 101-111, 2015. Disponível em: $<$ https://aplicacoes.ifs.edu.br/periodicos/index.php/caminhos_da_educacao_matematica/articl e/view/46/31 >. Acessado em: 19 dez. 2018

PEIRCE, Charles Sanders.: CP = Collected Papers of Charles Sanders Peirce. Vol. I-VI, ed. by Charles Hartshorne and Paul Weiß, Cambridge, Mass. (Harvard UP) 1931-1935, Vol. 
VII-VIII, ed. by Arthur W. Burks, Cambridge, Mass. (Harvard UP), 1958, (quoted by no. of volume and paragraph).

SANTAELLA, Lucia. O que é semiótica? São Paulo: Abril Cultural, 2007.

SILVA, Fernanda Ivo da. O pensamento relacional na geometria computadorizada. 2009. 122f Dissertação (Mestrado em Educação) - Universidade Federal de Mato Grosso, Cuiabá, 2009.

WIELEWSKI, Gladys Denise. O tabuleiro de xadrez: Uma perspectiva para a didática da Aritmética. 1998. 230f. Dissertação (Mestrado em Educação) - Universidade Federal de Mato Grosso, Mato Grosso, Cuiabá, 1998.

Recebido em: 22 de dezembro de 2018.

Aprovado em: 17 de maio de 2019. 